\title{
Port Governance Model by Managers' and Customers' Point of View: A Study at Port of Valencia, Spain
}

\author{
Guilherme Bergmann Borges Vieira ${ }^{1,2}$, Rafael Mozart da Silva ${ }^{1}$, Francisco José Kliemann Neto ${ }^{1}$, Luiz Afonso \\ dos Santos Senna ${ }^{1} \&$ Arturo Monfort Mulinas ${ }^{3}$ \\ ${ }^{1}$ Universidade Federal do Rio Grande do Sul, Porto Alegre, Brazil \\ ${ }^{2}$ Universidade de Caxias do Sul, Caxias do Sul, Brazil \\ ${ }^{3}$ Fundación Valenciaport, Valencia, Spain
}

Correspondence: Guilherme Bergmann Borges Vieira, Universidade Federal do Rio Grande do Sul, Porto Alegre, Brazil. Tel: 55-51-9944-8504. E-mail: gbvieira@cpovo.net

Received: May 24, 2014

Accepted: June 3, 2014

Online Published: July 25, 2014

doi:10.5539/ibr.v7n8p1

URL: http://dx.doi.org/10.5539/ibr.v7n8p1

\begin{abstract}
This paper shows a study of governance in the port of Valencia, Spain, based on a port governance conceptual model. The study follows a mixed approach (qualitative and quantitative) and it is based on primary data obtained through interviews with the port managers (qualitative phase) and questionnaires applied to port users (quantitative phase). The results show the applicability of the adopted port governance model, since its structure was useful for the analysis and understanding of the governance of port of Valencia. From the application of the model, an efficient and mature governance model was identified in the port of Valencia, which is perceived by the existing structure of governance, the actions of governance implemented and the results achieved, as evidenced both by the analysis of managers' and users' perception.
\end{abstract}

Keywords: port governance, model, managers, users, port of Valencia

\section{Introduction}

In recent decades, the number of studies dedicated to port management and governance has increased (Heaver, 2006). Some of these studies have addressed the ports as business agglomerations (clusters, logistics chains and logistics networks). This approach is important because port performance is the result of activities performed by several actors which need to be properly coordinated or governed (De Langen, 2004). This coordination takes place through a port governance model, which should consider the governance structure, the governance actions and the governance elements (Geiger, 2009), as well as the governance outcomes (Vieira, Kliemann Neto, \& Monfort-Mulinas, 2013).

Given this context, this study aims to analyze the governance model of the port of Valencia. This port is a reference in governance and in 2009 was considered best- in-class by the Port Cluster Governance Committee (PCGC) of the Global Institute of Logistics (GIL). This recognition was due to the maturity of its quality system to the port community, called Marca de Garantía, which guarantees a known minimum quality of services to the final customers, duly authorised and controlled by the Port Authority (López \& Poole, 1998), for presenting a committed and integrated port logistics chain; for the information systems that drive process improvement and support the coordination of the different actors involved in the port; for the leadership of the Port Authority of Valencia (APV) and its research and training arm, Fundación Valenciaport (FV), in the process of coordination of the port community, and the good relations port-city evidenced in Valencia. According to FV data, Valencia is the first commercial port of Spain with regard to container throughput, it is among the top ten in Europe and among the top 50 in the world, ranking 30th place in the world in 2012 in the ranking put by the World Shipping Council with 4.47 million TEUs (Twenty-foot Equivalent Units).

The chief discussion regarding port governance models focuses on the need to measure the different dimensions and variables associated with these models as well as the relationship between them and port performance. Given this context, the main objective of this study is to analyse Valencia's port governance by managers and users point of view and explore some relations regarding port governance and port performance. 


\section{Port Governance Model}

According to Geiger (2009), a governance model must answer three basic questions: Who governs? What is governed? and How is it governed? The answers to these questions are, respectively: i) governance structure, ii) governance actions, and iii) governance elements. The governance structure refers to the institutional and regulatory framework existing in business clustering; governance actions are the mechanisms inducing coordination and governance elements are the actors and the associated logistics flows. In addition to these three questions, a previous question can be formulated - Why is it (the port) governed? - which is linked to the governance outcomes (Vieira, Kliemann Neto, \& Monfort-Mulinas, 2013). The governance outcomes are associated with the effectiveness and efficiency of the port logistics chain. The ultimate objective of port governance is to promote port performance through a specific governance model (De Langen, 2004; Baltazar \& Brooks, 2006; Brooks \& Cullinane, 2006a; Cullinane, Yap, \& Lam, 2006; Brooks \& Pallis, 2008; Xu \& Chin, 2012; Lam, Ng, \& Xu, 2013).

Despite its importance, few models of port governance are found in the literature, namely the Baltazar \& Brooks model (2006) - detailed in later studies by Brooks \& Cullinane (2006b) and Brooks \& Pallis (2008); the Brooks \& Cullinane model (2006c); the Verhoeven model (2010) and the Milan \& Vieira model (2011), in addition to the models of port management and ownership by the World Bank (2001). Of these models, the first three stand out, given that the Brooks and Cullinane (2006c), Verhoeven (2010) and World Bank (2001) models focus only on port structure and functions and the Milan \& Vieira one (2011) only examines the governance actions. Therefore, these models do not address the relationship between governance and performance broadly enough and, therefore, have limited applicability. In addition, the Baltazar \& Brooks model (2006) and its subsequent adjustments proposed by Brooks \& Cullinane (2006b) and Brooks \& Pallis (2008) also show gaps as identified by Vieira, Kliemann Neto \& Monfort-Mulinas (2013). The gaps identified by the authors in these models were the following: i) the governance outcomes are not sufficiently detailed; ii) a broader discussion about typology of governance actions and means of implementation is missing; iii) the aspects related to the actors of the port logistics chain and the logistics flows arising from the interaction between these actors are not covered; and iv) the models do not have a means to be implemented in a process of port reform, which limits its applicability.

Aiming to fill these gaps, Vieira, Kliemann Neto, \& Monfort-Mulinas (2013) developed a new model based on the dimensions of governance proposed by Geiger (2009) and which includes an additional dimension governance outcomes. The conceptual framework of the model is shown in Figure 1.

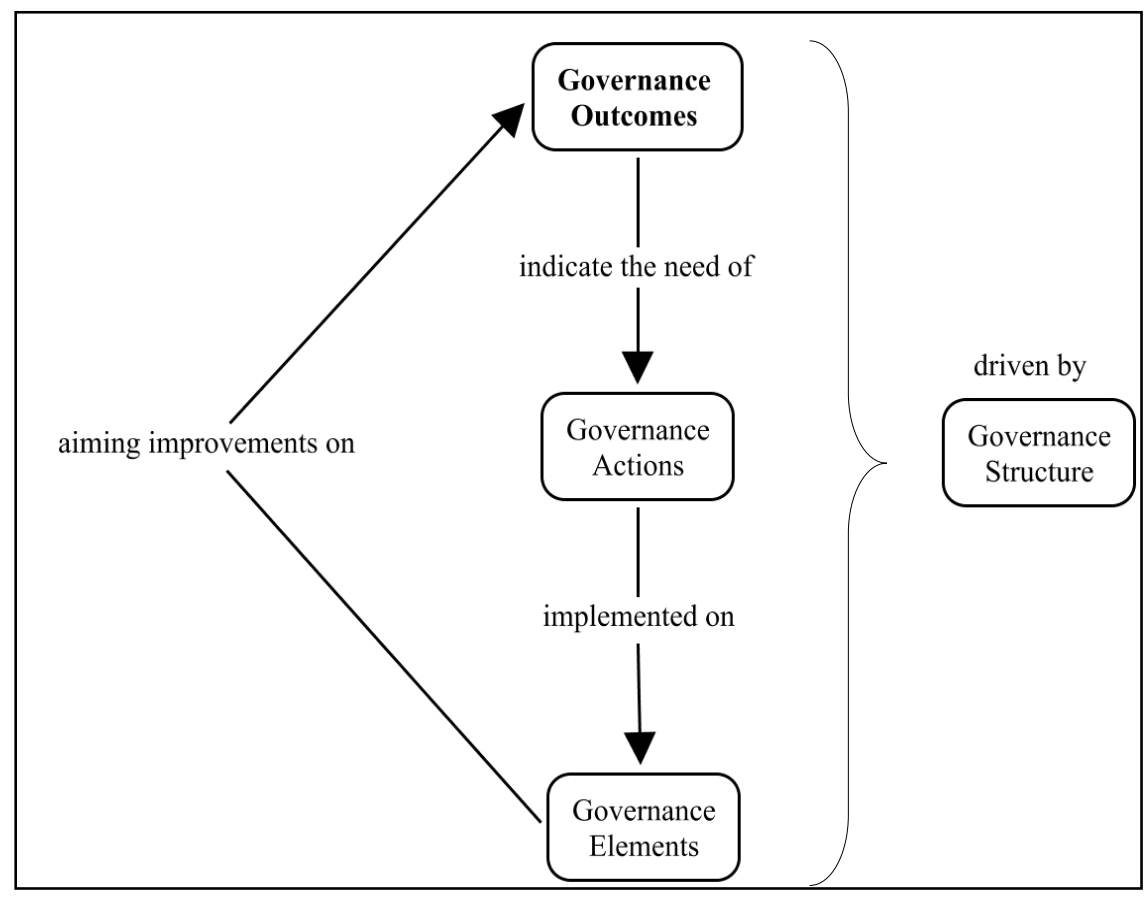

Figure 1. Port governance model 
The logic of this model is that the governance outcomes indicate the need for governance actions in order to increase the integration of the port logistics chain and the efficiency of the related flows, which are the governance elements, all driven by the existing governance structure. Given the need for measuring the governance of port logistics chains, the authors proposed a breakdown of each proposed dimension of the model (Figure 1) in some factors (Table 1). This breakdown allows for an evaluation of these factors by managers-by conducting interviews-and by the users-by applying questionnaires based on assertions for each factor, evaluated by a Likert scale. The basic assumption is that an appropriate governance model promotes the integration of the actors, which, in turn, facilitates the coordination of logistics flows, thus increasing efficiency.

Table 1. Dimensions and factors of the governance model of port logistics chains

\begin{tabular}{|c|c|}
\hline Dimensions & Factors \\
\hline Governance & - Port effectiveness \\
\hline \multirow[t]{4}{*}{ Outcomes } & - Port efficiency \\
\hline & - Port costs \\
\hline & - Maritime connections (number of liner shipping services) \\
\hline & - Frequency of liner shipping services \\
\hline Governance & - Existence of a governance structure \\
\hline \multirow[t]{2}{*}{ Structure } & - Effectiveness of the governance structure \\
\hline & - Improvement of the governance structure over time \\
\hline Governance & - Existence of governance actions for the coordination of the actors of port logistics chain \\
\hline \multirow[t]{4}{*}{ Actions } & - Existence of governance actions to coordinate the containers flow in this chain \\
\hline & - Existence of governance actions to coordinate the information flow \\
\hline & - Effectiveness of governance actions \\
\hline & - Improvement of governance actions over time \\
\hline Governance & - Coordination of the actors within the port logistics chain \\
\hline \multirow[t]{5}{*}{ Elements } & - Increasing of coordination over time \\
\hline & - Efficiency of container port logistics flow \\
\hline & - Increasing of containers flow efficiency over time \\
\hline & - Efficiency of information flow \\
\hline & - Increasing of information flow efficiency over time \\
\hline
\end{tabular}

Source: Vieira, Kliemann Neto, \& Monfort-Mulinas (2013).

The port governance model should provide a framework that facilitates the execution of actions, which, in turn, allow actors and flows to be coordinated, generating an increase in the efficiency and efficacy of the port logistics chain. The structure should be decentralized enough to allow the effective management of ports - given the local conditions and the need for understanding the demands of the port environment - and centralized enough to allow the coordination of the port system and the creation of an appropriate competitive environment, avoiding, for example, lack of regulation that generates overcapacity. Actions of governance may vary, but initiatives stand out regarding: i) the quality of the port logistics chain; ii) the information technologies used to integrate actors and flows; iii) the training of the actors within the port logistics chain; and iv) the management of port-city relationships (Milan \& Vieira, 2011). Figure 2 shows the steps for the application of the governance model on a port reform process. 


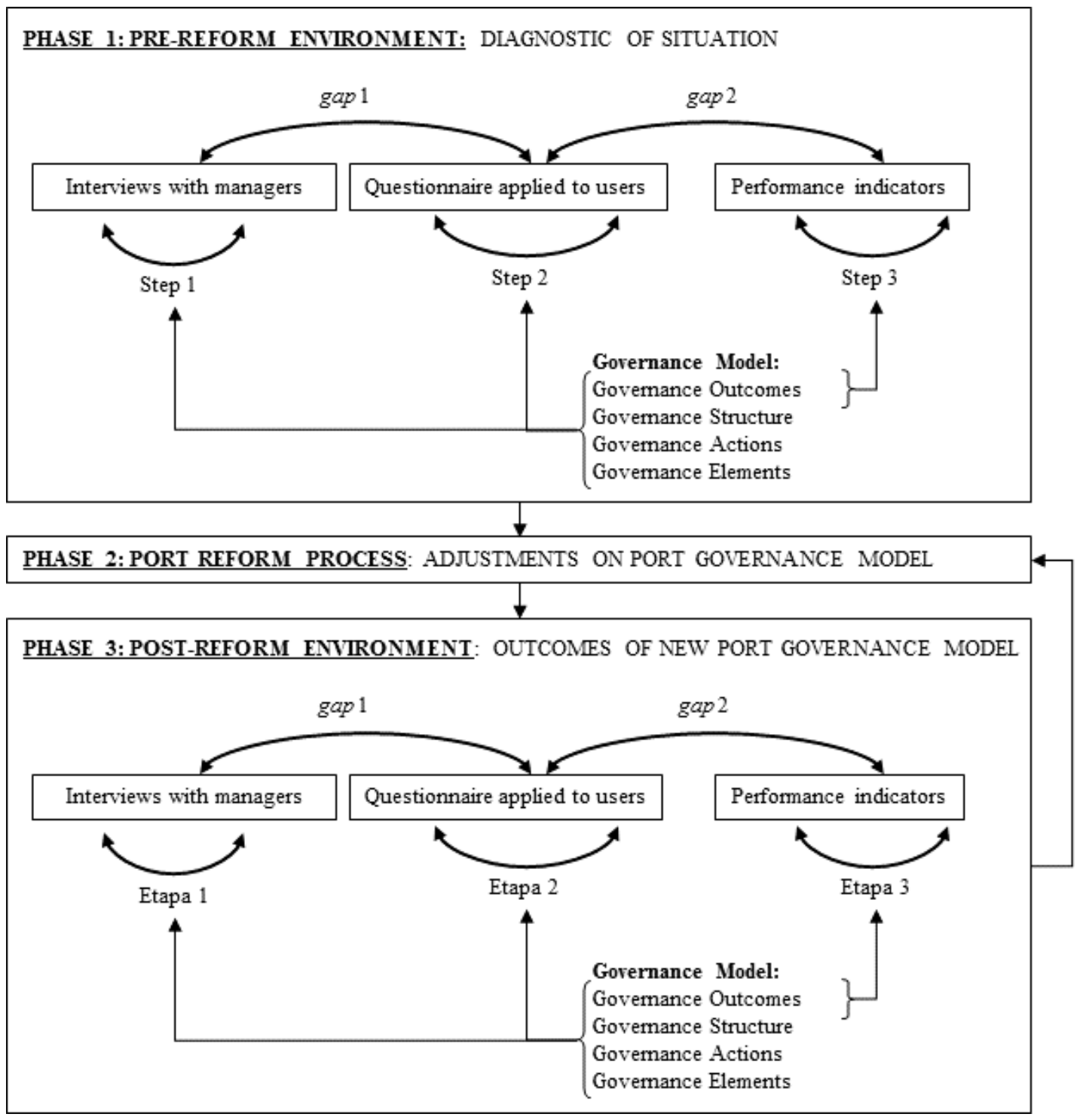

Figure 2. Steps for the application of the model in a process of port reform

Source: Vieira, Kliemann Neto, \& Monfort-Mulinas (2013).

From the model proposed by Vieira, Kliemann Neto, \& Monfort-Mulinas (2013), there is a comprehensive and structured logic to guide the port reform process, allowing adjustments in the existing governance model, aiming to better governance of the port logistics chain as well as greater competitiveness of this chain. In order to attain that, a systematic evaluation of port logistics chains in different dimensions of the model (structure, actions, elements and outcomes) is needed.

\section{Method}

This article is a descriptive study of mixed approach, comprising qualitative and quantitative phases. The data collection was based on: i) in-depth interviews with managers of the port of Valencia; and ii) questionnaires with users acting in such port.

In the first step (qualitative), the following managers in the port of Valencia were interviewed: i) the General Director of APV; ii) the Chief of Staff of APV Presidency; iii) the Director of Research, Development and Innovation of FV; iv) the Project Director of FV; v) the Director of Innovation of APV; vi) the Director of Marca de Garantía of APV; vii) the Director of Strategic Planning of APV; viii) the Director of the logistics activities of the port logistics zone (ZAL); and ix) the Deputy Director of General Services of APV. 
A set of questions comprising six open-ended questions was used, based on the governance model proposed by Vieira, Kliemann Neto, \& Monfort-Mulinas (2013). It should be emphasized that the present study focused on Phase 1 of the proposed model (Figure 2), generating elements that could potentially support the following phases (2 and 3). The interviews started with an initial question, of introductory nature, aimed to assess the overall perception of the interviewee on the evolution of port governance. After that, each interviewee was presented with the conceptual model and its dimensions (outcomes, structure, actions and elements of governance), followed by four key questions in order to identify how governance has evolved in that port regarding each model dimension. The interviews were rounded up with a final question in which what could (or should) change in the structure, actions and elements of governance was assessed, in order to generate better outcomes.

Interviews lasted between 1:00 and 2:00 hours. Not all interviewees answered all questions, due to the specificity of their fields. However, all questions were answered by at least four interviewees, which allowed good understanding (Table 2).

Table 2. Questions answered by each interviewee

\begin{tabular}{lcccccc}
\hline \multirow{2}{*}{ Interviewees } & \multicolumn{5}{c}{ Questions } \\
\cline { 2 - 7 } & Q1 & Q2 & Q3 & Q4 & Q5 & Q6 \\
\hline EV1 & $\mathrm{X}$ & $\mathrm{X}$ & $\mathrm{X}$ & & & \\
EV2 & & $\mathrm{X}$ & $\mathrm{X}$ & & & $\mathrm{X}$ \\
EV3 & $\mathrm{X}$ & $\mathrm{X}$ & $\mathrm{X}$ & $\mathrm{X}$ & $\mathrm{X}$ & $\mathrm{X}$ \\
EV4 & $\mathrm{X}$ & & $\mathrm{X}$ & & & $\mathrm{X}$ \\
EV5 & $\mathrm{X}$ & $\mathrm{X}$ & $\mathrm{X}$ & $\mathrm{X}$ & $\mathrm{X}$ & $\mathrm{X}$ \\
EV6 & $\mathrm{X}$ & $\mathrm{X}$ & $\mathrm{X}$ & $\mathrm{X}$ & $\mathrm{X}$ & $\mathrm{X}$ \\
EV7 & & $\mathrm{X}$ & & & & \\
EV8 & & $\mathrm{X}$ & $\mathrm{X}$ & $\mathrm{X}$ & & \\
EV9 & $\mathrm{X}$ & & $\mathrm{X}$ & $\mathrm{X}$ & $\mathrm{X}$ & $\mathrm{X}$ \\
Total & $\mathbf{6}$ & $\mathbf{7}$ & $\mathbf{8}$ & $\mathbf{5}$ & $\mathbf{4}$ & $\mathbf{6}$ \\
\hline
\end{tabular}

Following the interviews, the contents were analyzed, which identified the main characteristics of Valencia's port governance model, as well as possible opportunities for improvement.

In the second phase (quantitative), questionnaires were sent to users of the port logistics chain, also based on the proposed governance model and its dimensions. At this step, each dimension was broken down into a few factors according to Table 1. For each of these factors a statement was written, which was evaluated using a seven-point Likert scale (1. Strongly Disagree to 7. Strongly Agree). Moreover, some questions were asked in order to qualify companies and respondents (time with company; volume of containers handled, length of experience of the respondent etc.).

As a population, International Freight Forwarders (IFFs) were considered. The existing directory of companies available on the Port Authority of Valencia (APV) website was considered as a population, totaling 208 companies. We opted to send the questionnaires to the IFFs and not directly to exporters and importers due to the fact that, according to Malchow \& Kanafani (2004), IFFs are key influencers of the port selection process. Supporting this idea, the managers of the Port of Valencia stated that the port has almost no contact with exporters and importers, liaising only with IFFs. Therefore, the port choice process depends on selection of an IFF that provides a service through the port. After the application of questionnaires, a number of 30 valid questionnaires was obtained out of 208 questionnaires sent.

With the analysis of data collected in two phases, the port governance model were analyzed both from the perspective of managers (qualitative phase) and the users' point of view (quantitative phase), which enabled the examination of the differences between the perceptions of the two groups. The results obtained with the application of the proposed model allowed: i) to critically analyze their strengths and limitations, ii) to analyze governance model of port of Valencia; and iii) to explore relationships between the outcomes, the structure, the 
actions and the elements of governance in such port.

\section{Results}

This section shows an analysis of the governance model of the port of Valencia from the perspective of managers and users.

\subsection{Governance of the Port of Valencia in the Managers' Point of View}

In this section, the results of interviews conducted in Valencia are presented. Questions are numbered Q1 to Q6 and interviewees are coded EV1 to EV9. The presentation of results follows the order of questions.

\section{Q1: General perception on the evolution of port governance}

Interviewees EV1 and EV3 stated that governance should be analyzed in the context of the existing legal framework, represented by the Port Law of 1992 and its subsequent amendments, which allowed greater autonomy both for the autonomous communities in the port management and the port authorities themselves. Interviewees EV1 and EV2 mentioned within the landlord model the importance of analyzing how far responsibilities of the central government and the port authority go. EV1 highlighted the importance of timeliness in the granting process, and in order to do so, the right degree of decentralization in decision making is needed.

Interviewee EV4 mentioned the role of Fundación Valenciaport (Valenciaport Foundation) (FV) and the projects it has developed, while interviewee EV5 mentioned the role of Information and Communication Technology (ICT) in the governance of the port logistics chain. Interviewee EV6, in turn, highlighted the Marca de Garantía - the quality assurance system of the port community of Valencia - as a driving element of the governance of the port logistics chain, detailing its evolution over time.

Analyzing the content of the interviewees' answers, six major factors were identified: i) the existing legal framework; ii) the autonomy of the port authority; iii) the agility of the concession process; iv) the foundation of Fundación Valenciaport; v) the development of Information and Communication technologies and vi) the development of Marca de Garantía.

\section{Q2: Evolution of governance structure}

Interviewees EV1 and EV2 mentioned that, within the existing legal framework, governance depends largely on the actions defined by the Board of Directors of the port authority, which involves different actors within the port logistics chain. Interviewee EV2 also mentioned the existence of a coordinating body and internal management the Port Authority, called Executive Committee, which is formed by the President of the Port Authority, the Head of Executive Office of the President, the General Director, the General Secretary and the directors of Strategic Planning and Processing, Infrastructure Planning and General Services. This committee meets weekly to address issues associated with port management.

Interviewees EV2 and EV8 highlighted the Department of Processing and Management Control as an important part of the structure of governance as it aims to foster the coordination of the various departments involved in the implementation of the strategic planning of the port. The Board of Quality of Marca de Garantía and the Fundación Valenciaport patronage were also mentioned by interviewee EV2 as important elements of governance structure.

Interviewee EV3 cited the existing norms and their variation as crucial for governance structure. The interviewee also mentioned that the current legislation gives a considerable degree of autonomy to the port authorities, whose functions are much more extensive and relevant than the Puertos del Estado ones, which is basically an organ of coordination and control. Besides the Port Law, interviewee EV7 mentioned the Law of State Contracts and the Budget Law as elements of the governance structure (normative framework in which the port sector is inserted).

According to interviewees EV3 and EV7, the control of Puertos del Estado on port authorities is made through an instrument called a Business Plan, prepared annually and agreed upon technical meetings between the port authority and Puertos del Estado, and approved by the Board of Directors of the port. The Business Plan sets out the objectives, goals and indicators for each port authority. In the case of Valencia, it is established based on the concepts of the Balanced Scorecard (Kaplan and Norton, 1996) and Strategy Maps (Kaplan \& Norton, 2004), as mentioned by interviewees EV2, EV3 and EV7. According to interviewee EV7, the Business Plan is prepared in a format previously established by Puertos del Estado, with a template available on the intranet of that body. Interviewee EV7 stated that there are three instruments in the strategic management of the port: i) Strategic Planning, long-term oriented; iii) the Plan of Infrastructure Use, also long-term, and iii) the Business Plan, short-term. All these instruments are a result of the Port Law. 
According to interviewees EV5 and EV6, the Board of Quality of Marca de Garantía is the main existing structure of governance. Interviewee EV6 added that such a council is chaired by the Director General of APV.

Table 3 shows the factors identified in the responses of the nine interviewees.

Table 3. Factors associated with the structure of governance of the port of Valencia

\begin{tabular}{|c|c|c|c|c|c|c|c|c|c|c|}
\hline \multirow{2}{*}{ Factors } & \multicolumn{9}{|c|}{ Interviewees } & \multirow{2}{*}{ Total } \\
\hline & EV1 & EV2 & EV3 & EV4 & EV5 & EV6 & EV7 & EV8 & EV9 & \\
\hline Business Plan & & $\mathrm{X}$ & $\mathrm{X}$ & & & & $\mathrm{X}$ & & & 3 \\
\hline Board of Directors of APV & $\mathrm{X}$ & $\mathrm{X}$ & & & & & & & & 2 \\
\hline $\begin{array}{l}\text { Department of Processing and } \\
\text { Management Control of APV }\end{array}$ & & $\mathrm{X}$ & & & & & & $\mathrm{x}$ & & 2 \\
\hline Board of Quality of Marca de Garantía & & $\mathrm{X}$ & & & $\mathrm{X}$ & & & & & 2 \\
\hline Executive Committee of APV & & $\mathrm{X}$ & & & & & & & & 1 \\
\hline Patronage of FV & & $\mathrm{X}$ & & & & & & & & 1 \\
\hline Existing legal framework & & & $\mathrm{X}$ & & & & & & & 1 \\
\hline Puertos del Estado and Port Authorities & & & $\mathrm{X}$ & & & & & & & 1 \\
\hline Law of State Contracts & & & & & & & $\mathrm{X}$ & & & 1 \\
\hline Budget Law & & & & & & & $\mathrm{X}$ & & & 1 \\
\hline Strategic Planning APV & & & & & & & $\mathrm{X}$ & & & 1 \\
\hline Plan of infrastructure use & & & & & & & $\mathrm{X}$ & & & 1 \\
\hline Total & 1 & 6 & 3 & $\mathbf{0}$ & 1 & $\mathbf{0}$ & 5 & 1 & & 17 \\
\hline
\end{tabular}

Three factors that can be considered actions of governance (Business Plan, Strategic Planning of the Port Authority and Plan of Infrastructure Use) were cited, which shows some overlap between the structure and the actions of governance from the users' perspective, especially the importance of the Business Plan, which was cited by three out of nine interviewees.

Q3: Evolution of governance actions

Regarding question 3 on the evolution of the actions for the coordination of the actors and the improvement of port logistics flows (cargo and information), interviewee EV1 said that what differentiates Valencia from other ports is the existence of a pro-active attitude of the port authority, based on staff training and the existence of entrepreneurial vision. In this sense, according to the interviewee, various actions in the areas of education, innovation, quality, information technology and strategic planning are made.

In a little more detail, interviewee EV2 cited as actions of governance: i) the Marca de Garantía of the port of Valencia, ii) the development of ICTs, especially the Port Community System (PCS) of the port; iii) the creation of Fundación Valenciaport (FV); iv) the co-operation of the port of Valencia with various national and international bodies and v) the environmental projects implemented in the port logistics chain.

As for FV, interviewee EV2 stated that it works closely with APV. According to the interviewee, FV it is a supplementary means of integration of the port community that transcends the commercial sector. Interviewee EV2 also mentioned actions of Corporate Social Responsibility (CSR) implemented by the port authority and aimed at three different groups: i) the port authority human resources; ii) the different actors of the port logistics chain and iii) the civil society. Another element mentioned by interviewee EV2 was the strategic planning of the port, developed with the support of an international consulting group and the involvement of different actors related to the port.

Interviewee EV3, in turn, mentioned eight actions of governance that have been developed in Valencia, part of which also cited by interviewee EV2: i) training activities for the port logistics community developed since the early 90s by Instituto Portuario de Estudios y Cooperación (IPEC), which originated FV in 2004; ii) the development of Marca de Garantía of the Port of Valencia; iii) the implementation of ICT in port logistics processes; iv) environmental management (Ecoport project); v) the implementation of the BSC for the strategic 
management of the port authority; vi) the creation of VPI Logistics, intermodal and logistics platform of the port of Valencia; vii) development of RSC (Social Corporate Responsibility) initiatives and viii) improvement of port-city relationships.

Interviewees EV3 and EV4 highlighted the role of FV, which is a center for research, training and cooperation in the service of the actors involved in the port logistics chain and aims to improve the competitiveness of this chain.

Interviewee EV3 mentioned the integration between FV and APV. Interviewee EV4 mentioned that the organizational structure comprises an FV employer and an executive committee. The patronage is the supreme organ of government, administration and representation of FV, consisting of 20 members coming from 16 entities of the port cluster. Employers have a president, who is elected by APV. The executive committee, in turn, is composed of the President and four members of the patronage. This shows the relationship between APV and FV.

For interviewee EV5, the main actions of governance are the development of Marca de Garantía under the leadership of APV, and actions associated with the Port Community System (PCS) of the port, which allowed increased efficiency through better management of operations on the patio and on the pier, including electronic and one-time-only transmission of documents and the removal of containers without paperwork, among other factors. Marca de Garantía was also cited by interviewee EV8, who mentioned its importance as a philosophy of quality and as a marketing tool, which influences the perception of customer value as well as the choice of port. However, EV8 interviewee pointed out that while the port of Valencia has been a pioneer, now many ports have similar initiatives, albeit with different names. Interviewee EV5 also cited the management of port infrastructure.

According to interviewee EV6, the actions of governance are the decisions made by the Board of Quality of Marca de Garantía, of which the major actors of the port logistics chain are part. Furthermore, the interviewee mentioned that alongside Marca de Garantía, ICTs have been developed applied to port logistics processes. As an example of the relationship between these two actions of governance, the interviewee reported that Marca de Garantía establishes in its guidelines that all participating companies must use the PCS that connects and integrates the port logistics chain.

Interviewee EV9 mentioned communication as an act of governance, highlighting the importance of the intranet of the port for sharing useful information with management, both those related to the BSC and other. Interviewee EV9 also mentioned by as actions of governance: the development of ICTs, the Brand Guarantee, environmental initiatives and the creation of the Fundación Valenciaport. In summary, with regard to actions of governance ten factors were mentioned, as shown in Table 4.

Table 4. Factors associated with actions of governance in the port of Valencia

\begin{tabular}{|c|c|c|c|c|c|c|c|c|c|c|}
\hline \multirow[t]{2}{*}{ Factors } & \multicolumn{9}{|c|}{ Interviewees } & \multirow[b]{2}{*}{ Total } \\
\hline & EV1 & EV2 & EV3 & EV4 & EV5 & EV6 & EV7 & EV8 & EV9 & \\
\hline Marca de Garantía & & $\mathrm{X}$ & $X$ & & $X$ & $\mathrm{X}$ & & $\mathrm{X}$ & & 5 \\
\hline Development of ICT & & $\mathrm{X}$ & $\mathrm{X}$ & & $\mathrm{X}$ & $\mathrm{X}$ & & & $\mathrm{X}$ & 5 \\
\hline Performance of FV & $\mathrm{X}$ & $\mathrm{X}$ & $\mathrm{X}$ & $\mathrm{X}$ & & & & & $\mathrm{X}$ & 5 \\
\hline $\begin{array}{l}\text { Environmental projects in the port } \\
\text { logistics chain }\end{array}$ & & $\mathrm{X}$ & $\mathrm{X}$ & & & & & & $\mathrm{X}$ & 3 \\
\hline Actions of Social Responsibility & & $\mathrm{X}$ & $\mathrm{X}$ & & & & & & & 2 \\
\hline Strategic planning of the port & & $\mathrm{X}$ & $\mathrm{X}$ & & & & & & & 2 \\
\hline $\begin{array}{l}\text { Cooperation with national and } \\
\text { international bodies }\end{array}$ & & $\mathrm{X}$ & & & & & & & & 1 \\
\hline Creation of VPL logistics & & & $\mathrm{X}$ & & & & & & & 1 \\
\hline Improvement of port-city relationships & & & $\mathrm{X}$ & & & & & & & 1 \\
\hline Management of port infrastructure & & & & & $\mathrm{X}$ & & & & & 1 \\
\hline Total & 1 & 7 & 8 & 1 & 3 & 2 & 0 & 1 & 3 & 26 \\
\hline
\end{tabular}


Among the factors cited, the Marca de Garantía, the development of ICT and the role of Fundación Valenciaport stand out.

Q4: Evolution of the governance elements

As for question 4, on how the coordination of the actors in the port logistics chain has evolved and the efficiency of port logistics activities in the port, interviewee EV3 mentioned that actions of governance have contributed significantly.

Interviewee EV6 stated that the Marca de Garantía generated a significant cultural change, with the substitution of an individualistic vision for a group vision. After that, a more mature, connected and coordinated port community was created.

Interviewees EV5, EV8 and EV9, in turn, mentioned the increase in productivity due to technological changes, which have enabled improvements in processes, considering the different actors involved. According to interviewee EV9, this allows the service (or even the anticipation) of international quality requirements in the areas of safety, environment and ICT.

It is clear, therefore, that the main factors cited as the elements of governance have increased productivity and efficiency of logistics operations and enhanced coordination between the actors, as shown in Table 5.

Table 5. Factors associated with elements of governance in the port of Valencia

\begin{tabular}{|c|c|c|c|c|c|c|c|c|c|c|}
\hline \multirow[t]{2}{*}{ Factors } & \multicolumn{9}{|c|}{ Interviewees } & \multirow[b]{2}{*}{ Total } \\
\hline & EV1 & EV2 & EV3 & EV4 & EV5 & EV6 & EV7 & EV8 & EV9 & \\
\hline $\begin{array}{l}\text { Logistics operations: increased productivity } \\
\text { and efficiency }\end{array}$ & & & $\mathrm{X}$ & & $\mathrm{X}$ & & & $\mathrm{X}$ & & 3 \\
\hline $\begin{array}{l}\text { Port logistics chain: cohesion / enhanced } \\
\text { coordination among actors in the chain }\end{array}$ & & & $\mathrm{X}$ & & & $\mathrm{X}$ & & & $X$ & 3 \\
\hline $\begin{array}{l}\text { Culture: development of a collaborative } \\
\text { posture / group vision }\end{array}$ & & & & & & & & $\mathrm{X}$ & & 1 \\
\hline $\begin{array}{l}\text { Quality: anticipation of international } \\
\text { requirements on safety, environment and ICT }\end{array}$ & & & & & & & & & $X$ & 1 \\
\hline Total & 0 & 0 & 2 & 0 & 1 & 1 & 0 & 2 & 2 & 8 \\
\hline
\end{tabular}

\section{Q5: Evolution of governance outcomes}

Regarding to the performance of the port over time (Q5), according to interviewee EV3 the improvement of governance elements $(\mathrm{Q} 4)$ has favored port performance as a whole. However, the interviewee mentioned that although there is a relationship between the structure and actions of governance and port performance, the latter is also influenced by a number of other factors, so that it becomes difficult to measure this relationship, an aspect also mentioned by interviewee EV9, who argued that actions of governance implemented in the port logistics chain end up contributing to the improvement of the reputation of the port, thus influencing the choice of port. Interviewee EV3 also mentioned that infrastructure is a necessary-but not sufficient-aspect for port performance, and that the existing structure and actions of governance allow a better use of that infrastructure.

Interviewee EV5 also mentioned the existence of a clear relationship between actions of governance (Marca de Garantía and PCS) and port performance, providing greater simplicity and uniformity in procedures. According to the interviewee, the productivity of cranes increased considerably (from 15 to 24 movements per hour) as a function of these actions.

Interviewee EV6 cited the culture change driven by Marca de Garantía as the main outcome of governance, which served as an effective means for improving processes. Operational improvements were cited, such as: i) increase in productivity; ii) greater efficiency in processes; and iii) greater integration between the actors of the chain.

Table 6 shows the main factors associated with the outcomes of governance in the port of Valencia. 
Table 6. Factors associated with outcomes of governance in the port of Valencia

\begin{tabular}{|c|c|c|c|c|c|c|c|c|c|c|}
\hline \multirow[t]{2}{*}{ Factors } & \multicolumn{9}{|c|}{ Interviewees } & \multirow[b]{2}{*}{ Tota } \\
\hline & EV1 & EV2 & EV3 & EV4 & EV5 & EV6 & EV7 & EV8 & EV9 & \\
\hline $\begin{array}{l}\text { Better use of port infrastructure / higher } \\
\text { productivity and efficiency }\end{array}$ & & & $\mathrm{X}$ & & $\mathrm{X}$ & $\mathrm{X}$ & & & & 3 \\
\hline $\begin{array}{l}\text { Difficulty of measuring the relationship } \\
\text { between governance and port performance }\end{array}$ & & & $\mathrm{X}$ & & & & & & $\mathrm{X}$ & 2 \\
\hline $\begin{array}{l}\text { Clear relationship between governance } \\
\text { actions (Marca de Garantía and PCS) and } \\
\text { port performance }\end{array}$ & & & & & $\mathrm{X}$ & & & & & 1 \\
\hline $\begin{array}{l}\text { Improvement of governance elements, } \\
\text { favoring port performance as a whole }\end{array}$ & & & $\mathrm{X}$ & & & & & & & 1 \\
\hline Cultural change & & & & & & $\mathrm{X}$ & & & & 1 \\
\hline Greater integration between the port actors & & & & & & $\mathrm{X}$ & & & & 1 \\
\hline Improvement of the port reputation & & & & & & & & & $\mathrm{X}$ & 1 \\
\hline Total & 0 & 0 & 3 & 0 & 2 & 3 & 0 & 0 & 2 & 10 \\
\hline
\end{tabular}

As shown in Table 6, the main factor cited was the increased efficiency of the processes, mentioned by three interviewees. This increased efficiency has allowed a better use of port infrastructure and increased operational productivity. However, the difficulty of measuring the relationship between governance and port performance stands out.

\section{Q6: Opportunities for the improvement of the governance model}

When asked about what could (or should) be changed in governance structure, actions and elements to achieve better outcomes (question 6), interviewee EV2 stated that it is necessary to seek greater coordination of actors in the port logistics chain. The interviewee also stated that if there was greater independence of the port authority, there would be better governance. Still according to interviewee EV2, there is the need to develop a management tool that allows automatic and continuous monitoring of the indicators used in the BSC. According to him, many of them need to be collected whenever it is necessary to create management reports for Puertos del Estado.

Interviewee EV3 mentioned the lack of autonomy for the establishment of a global port network due to the existing regulatory system. The interviewee also mentioned that the port - city relationships are limited and that any work of revitalization is not the responsibility of the port authority, but of the municipality.

Interviewee EV4, in turn, mentioned that there could be greater integration between the strategies of APV and FV. However, the interviewee mentioned that FV develops a work proposal every year, detailing a set of projects to be developed, which is presented to a follow-up committee, composed of the General Director and the Director of Strategic Planning and Processing of APV as well as the General Director and the Project Director of FV, making adjustments if needed. After the adjustment (if applicable), the approval is made by the patronage of FV and the Board Council of APV. Although there is this joint approval, interviewee EV4 said that the relationship between middle managers of APV and FV is informal, which hinders the implementation of actions associated with each project. According to the interviewee, a possible next step would be to create follow-up subcommittees (one for each project) to formalize this relationship, generating a greater commitment of those involved and facilitating the emergence of new ideas. These subcommittees would work as a mechanism to strengthen the integration between APV and FV.

Interviewee EV5 cited the lack of a global vision of ICT, since the solutions arise from working groups (associated with the Board of Quality of Marca de Garantía) in a segmented way. The solution proposed by the interviewee would be the creation of an advisory group of ICT, integrating all existing working groups.

Interviewee EV5 also mentioned that there are some parallels in information systems, which may influence the efficiency of operations and, consequently, the port choice of most users (especially the owners). As an example, interviewee EV5 cited the existence of two systems of sanitary inspection in operation-one from Spain (SISAEX) and other from the European Union (TRACES) - mentioning that there are also other local examples.

Interviewee EV5 also cited the need for greater use of rail transport for the delivery and removal of containers at 
the port, mentioning that there is already a move in this direction, which is the increase of rail capacity to support trains of greater length. This capacity, which is currently 400 meters, will be 750 meters long, thus allowing longer trains.

Interviewee EV5 also mentioned the existence of certain inertia in the innovation process, due to the maturity the port has already reached. According to the interviewee, it is necessary to think about new advances in automation, since the port is probably near its limit productivity regarding technologies currently in use. Another possible improvement would be to seek greater harmonization of procedures at European level.

Regarding what should be changed to improve governance at the port, interviewee EV6 stated that there should be continuous monitoring of the indicators to be considered for the establishment of financial compensation expected by Marca de Garantía. According to the interviewee, the process to date has occurred through a retrospective analysis and preparation of a report on the occurrence of any non-compliance, with the whole process taking less than a week. Along with the need for improvement, he highlighted the importance of human resources to continuously analyze these indicators and support the integration between different workgroups, allowing the creation of new guarantees as well as the continuous improvement of existing ones. However, interviewee EV6 said that these improvements are punctual, showing there is no convergence among interviewees.

As a possible improvement, interviewee EV9 mentioned the need to develop a system to watch the markets to detect trends and analyze scenarios in order to anticipate opportunities and threats to a possible extent.

For the aspects that could or should be improved in Valencia's port governance several specific factors have been cited, not showing convergence among interviewees (Table 7). Only one factor was mentioned more than once. This is about the search for less public intervention/ greater autonomy. The major contributions in this regard were mentioned by interviewees EV5 and EV2.

Table 7. Opportunities for improvement in governance for the port of Valencia

\begin{tabular}{|c|c|c|c|c|c|c|c|c|c|c|}
\hline \multirow[t]{2}{*}{ Factors } & \multicolumn{9}{|c|}{ Interviewees } & \multirow[b]{2}{*}{ Total } \\
\hline & EV1 & EV2 & EV3 & EV4 & EV5 & EV6 & EV7 & EV8 & EV9 & \\
\hline Less public intervention (greater autonomy) & & $\mathrm{X}$ & $\mathrm{X}$ & & & & & & & 2 \\
\hline Greater commitment from the chain actors & & $\mathrm{X}$ & & & & & & & & 1 \\
\hline $\begin{array}{l}\text { Development of a management tool to } \\
\text { automatically and constant track the BSC } \\
\text { indicators }\end{array}$ & & $\mathrm{X}$ & & & & & & & & 1 \\
\hline $\begin{array}{l}\text { Greater integration between the APV and FV } \\
\text { strategies }\end{array}$ & & & & $\mathrm{X}$ & & & & & & 1 \\
\hline $\begin{array}{l}\text { Lack of ICT parallelism global vision in } \\
\text { information systems }\end{array}$ & & & & & $\mathrm{X}$ & & & & & 1 \\
\hline Greater use of rail transport & & & & & $\mathrm{X}$ & & & & & 1 \\
\hline $\begin{array}{l}\text { Inertia in the innovation process, due to } \\
\text { maturity reached by the port }\end{array}$ & & & & & $\mathrm{X}$ & & & & & 1 \\
\hline $\begin{array}{l}\text { Need for advances in productivity border } \\
\text { closeness/automation with the technologies } \\
\text { currently employed }\end{array}$ & & & & & $\mathrm{X}$ & & & & & 1 \\
\hline Harmonization of procedures at European level & & & & & $\mathrm{X}$ & & & & & 1 \\
\hline $\begin{array}{l}\text { Follow up of the indicators considered for } \\
\text { establishing the financial compensation set } \\
\text { down by the Marca da Garantía }\end{array}$ & & & & & & $\mathrm{X}$ & & & & 1 \\
\hline $\begin{array}{l}\text { Creation of an observatory to detect market } \\
\text { trends and analyze scenarios, in order to } \\
\text { anticipate threats and opportunities }\end{array}$ & & & & & & & & & $\mathrm{X}$ & 1 \\
\hline Total & 0 & 3 & 1 & 1 & 5 & 1 & 0 & 0 & 1 & 12 \\
\hline
\end{tabular}


The opportunities for improvement cited by managers aim at enhancing the governance model implemented in its various aspects (structure, management, elements, and outcomes). To a large extent, the opportunities for improvement cited focused on the governance in the port logistics chain (meso level) and the discussions include system simplification (processes) and operations automation.

\subsection{Governance of the Port of Valencia from the Users' Point of View}

This section presents the results of the port governance model evaluation made by IFFs. The sample used in the research is characterized by the following data: i) number of employees from the companies where the respondents work for; ii) companies' operation time in business; iii) annual quantity of containers handled (loading and unloading) in the port of Valencia; iv) percentage of containers handled (loading and unloading) on the total handled by companies; and v) respondents' work experience length.

Table 8 presents the distribution of responses according to the number of employees from companies where the respondents work. A concentration of respondents from companies with up to 50 employees was noticed - $80 \%$ of the respondents are linked to this type of company, and there was no registration of respondents from companies with over 300 employees.

Table 8. Number of employees from the companies where the respondents work

\begin{tabular}{ccc}
\hline $\mathrm{N}^{\circ}$ of Employees & $\mathrm{N}^{\circ}$ of answers & $\%$ \\
\hline 0 to 10 & 13 & $43.3 \%$ \\
11 to 50 & 11 & $36.7 \%$ \\
51 to 100 & 4 & $13.3 \%$ \\
101 to 300 & 2 & $6.7 \%$ \\
Total & 30 & $100.0 \%$ \\
\hline
\end{tabular}

Regarding to the length of time that companies operate in the market, the sample comprises 28 companies with over 10 years' time experience in business, a company with 5 to 10 years of experience, and another with 3 to 5 years. Therefore, a percent of $96.6 \%$ of the companies in which the respondents work for operate for over 5 years, and $93.3 \%$ for more than 10 years. With respect to the experience of respondents with port logistics operations and foreign trade, sample data revealed considerable variability, but a high average work experience time was noticed ( 22 years). In addition, no respondents presented less than five years of experience, which facilitates their understanding about the port logistics reality.

Table 9 presents the number of containers handled by the companies the respondents belong to in both export and import.

Table 9. Number of containers handled

\begin{tabular}{ccccc}
\hline \multirow{2}{*}{ Containers/ year } & \multicolumn{2}{c}{ Loaded } & \multicolumn{2}{c}{ Unloaded } \\
\cline { 2 - 5 } & $\mathrm{N}^{\circ}$ of answers & $\%$ & $\mathrm{~N}^{\circ}$ of answers & $\%$ \\
\hline Up to 10 & 0 & $0.0 \%$ & 3 & $10.0 \%$ \\
From 11 to 100 & 6 & $20.0 \%$ & 2 & $6.7 \%$ \\
From 101 to 1,000 & 12 & $40.0 \%$ & 13 & $43.3 \%$ \\
From 1,001 to 10,000 & 8 & $26.7 \%$ & 10 & $33.3 \%$ \\
Over 10,000 & 4 & $13.3 \%$ & 2 & $6.7 \%$ \\
Total & 30 & $100.0 \%$ & 30 & $100.0 \%$ \\
\hline
\end{tabular}

Valencia shows a concentration from 101 to 1,000 and from 1,001 to 10,000 containers per year, totaling $66.7 \%$ of the boarded and $76.6 \%$ of the landed containers. Table 3 presents the representativeness of the ports of Valencia and Santos in the total amount of containers boarded and landed by the companies which the respondents work for. The data shown in Table 3 show a significant representativeness in percentage terms of the ports of Valencia and Santos in the total handling of containers of the companies which the respondents work for. This percentage is, on average, more than $60 \%$, ranging from a minimum of $10 \%$ to a maximum of $100 \%$. 
Table 10. Percentage of containers handled over all operations in the port

\begin{tabular}{ccc}
\hline Percentage of Containers & \% Loaded & \% Unloaded \\
\hline Minimum & 20 & 10 \\
Maximum & 100 & 100 \\
Average & 65.8 & 67.8 \\
Standard Deviation & 23.8 & 25.3 \\
\hline
\end{tabular}

Data from Table 10 allow affirming that the analyzed ports are important for the companies, which suggests the need for a constant evaluation and justifies the users as an important source of information regarding port governance.

With respect to port governance model, the range over 5 in a scale ranging from 1 to 7 (Table 11) indicates that respondents agree with the statements presented in the questionnaire about the results, the structure, the actions and the elements of governance. In other words, the respondents agree that: i) the port meets their needs and offers efficient operations, as well as that maritime connections and frequency of regular shipping services are adequate; ii) there is a (normative and institutional) governance structure that facilitates the coordination of port logistics chain and that it has been improved over time; iii) actions for the coordination of port logistics chain has been developed and enhanced; and iv) there is port logistics chain coordination and such coordination has improved over time.

When punctually analyzing the results from the users' responses for the 19 statements of the questionnaire (Table 11), it can be seen that only for one question an average of less than 4 (Q3 3.53) was obtained, which indicates low concordance of the respondents with the statement that 'the port tariffs are competitive'. For the remaining 18 affirmatives, the averages of the responses were all close to or higher than 5, ranging from 4.97 to 5.87.

Table 11. Descriptive statistics

\begin{tabular}{ccc}
\hline Question/ Dimension & Average & Standard Deviation \\
\hline Question 1 & 5.3667 & 1.12903 \\
Question 2 & 5.4333 & 0.93526 \\
Question 3 & 3.5333 & 1.25212 \\
Question 4 & 5.8667 & 0.89955 \\
Question 5 & 5.8000 & 0.84690 \\
Outcomes & $\mathbf{5 . 2 0 0 0}$ & $\mathbf{0 . 7 4 0 9 2}$ \\
Question 6 & 5.1333 & 1.27937 \\
Question 7 & 4.9667 & 1.29943 \\
Question 8 & 5.4333 & 1.27802 \\
Structure & $\mathbf{5 . 1 7 7 8}$ & $\mathbf{1 . 2 0 5 7 8}$ \\
Question 9 & 5.0000 & 1.23176 \\
Question 10 & 4.9667 & 1.15917 \\
Question 11 & 5.2667 & 1.08066 \\
Question 12 & 4.9667 & 1.24522 \\
Question 13 & 5.5000 & 1.04221 \\
Actions & $\mathbf{5 . 1 4 0 0}$ & $\mathbf{0 . 9 7 5 7 8}$ \\
Question 14 & 4.9667 & 1.15917 \\
Question 15 & 5.4000 & 1.13259 \\
Question 16 & 5.0333 & 1.15917 \\
Question 17 & 5.3333 & 1.21296 \\
Question 18 & 5.3667 & 1.21721 \\
Question 19 & 5.7667 & 1.04000 \\
Elements & $\mathbf{5 . 3 1 1 1}$ & $\mathbf{1 . 0 3 2 7 3}$ \\
\hline & & \\
\hline & & \\
\hline & & \\
\hline & & \\
\hline
\end{tabular}




\section{Discussion}

The analyses of the interviews with managers (qualitative phase) and the questionnaires applied to users (quantitative phase) revealed a mature and well-structured governance model, as shown in Table 12, which presents a summary of the results of each phase.

Table 12. Summary of the outcomes

\begin{tabular}{lc}
\hline Qualitative Phase & Quantitative Phase \\
\hline - Active Posture of port authority regarding all dimensions of & $\begin{array}{c}\text { High degree of agreement from users regarding the existence } \\
\text { and adequacy of the dimensions of governance: }\end{array}$ \\
governance of port logistics & - Structure of Governance \\
$\begin{array}{l}\text { Puertos del Estado as governance body of the port system } \\
\text { - Strategy and marketing actions by the Port Authority and Port }\end{array}$ & - Actions of Governance \\
terminals & - Elements of Governance \\
\end{tabular}

Furthermore, no significant gaps were identified between the managers' and users' points of view. This alignment on the results obtained in the different phases of the study highlights the consistency of results and the proposed model itself, since, ideally, the governance model must be perceived similarly by managers and users, and should be corroborated by the performance indicators from the ports analyzed.

Managers cited the different aspects that reveal a mature, well-structured and constantly evolving governance model, driven by the APV. Users showed a degree of agreement over 5 (on a scale of 1 to 7 ) with the affirmatives presented in the questionnaire, which sought to measure their perception regarding the existence, relevance and evolution of governance structure, actions, elements and outcomes. However, the study also revealed some improvement opportunities for consideration by Valencia's Port Authority. Among these opportunities is the need to move forward in the development of information technologies and the improvement of port logistics processes.

Among the main findings of the study are the governance actions implemented in the port of Valencia. The study reveals that these governance actions create their own governance structures, allow greater coordination of actors and port logistics flows and potentiate governance outcomes (Table 13).

Table 13. Actions of governance and related structures in the port of Valencia

\begin{tabular}{llll}
\hline Actions & Structures & Elements & Outcomes \\
\hline Marca de Garantía & Marca de Garantía Board & & - Efficiency (corroborated by dwell \\
Port Community System (PCS) & Valenciaportpcs.net & -Port Logistics flows & time and costs of operations) \\
Training & Fundación Valenciaport (FV) & & - Effectiveness (corroborated by \\
Corporate Social & Port Authority CSR Department & -Logistics chain Actors & the perception of users) \\
Responsibility (CSR) & & - Competitive insertion (originated \\
\hline
\end{tabular}

Therefore, these governance actions are key aspects of governance in the port of Valencia and must be constantly monitored. Moreover, it can be considered good governance practices which serve as a reference to other ports.

Regarding the reliability and validity of the applied method, the model used was adequate for understanding port governance in its main dimensions and variables, and the results of the two research phases-qualitative and quantitative-were consistent. In addition, the method that can be replicated in other port logistics chains.

\section{Conclusions}

The present study has as its main contribution the implementation of the proposed governance model (which supplies the main gaps identified in the competing models) to the ports of Valencia. The analysis of this port from the proposed model showed the applicability of the model, since its dimensions (structure, actions, elements and outcomes of governance) and its application process proved to be useful for the evaluation of the 
governance of the ports studied. In addition, the analysis of Valencia's port governance in their two phases (from the managers' and users' point of view) can assist in the direction of improvement actions to be implemented in this port.

However, notwithstanding its contribution, some limitations from this study must be stressed. The first of these limitations relates to the partial application of the model, which was restricted to its phase 1 . Secondly, due to the fact that this is a cross-sectional study, it has not been possible to analyze the evolution of governance (and, in particular, the outcomes of governance) over time.

As an indication for future studies, it is suggested: i) the complete application of the model, considering a port reform process in its three phases and conducting a longitudinal analysis of the outcomes of governance at the different phases; ii) the application of the model to other kinds of cargo, making the adjustments that may be required; iii) application of the model to other ports, subject to different models of port management; and iv) promote an in-depth discussion on outcomes of governance from the studies that have already carried out on port performance analysis.

\section{References}

Baltazar, R., \& Brooks, M. R. (2006). Port governance, devolution and the Matching Framework: a configuration theory approach. Research in Transportation Economics, 17(1), $379-403$. http://dx.doi.org/10.1016/S0739-8859(06)17017-1

Brooks, M. R., \& Cullinane, K. (2006a). Introduction. Devolution, Port Governance and Port Performance. Research in Transportation Economics, 17(1), 3-28. http://dx.doi.org/10.1016/S0739-8859(06)17001-8

Brooks, M. R., \& Cullinane, K. (2006b). Conclusions and research agenda. Devolution, Port Governance and Port Performance. Research in Transportation Economics, 17(1), 631-660. http://dx.doi.org/10.1016/S0739-8859(06)17026-2

Brooks, M. R., \& Cullinane, K. (2006c). Governance models defined. Research in Transportation Economics, 17(1), 405-435. http://dx.doi.org/10.1016/S0739-8859(06)17018-3

Brooks, M. R., \& Pallis, A. A. (2008). Assessing port governance models: process and performance components. Maritime Policy and Management, 35(4), 411-432. http://dx.doi.org/10.1080/03088830802215060

Cullinane, K., Yap, W. Y., \& Lam, J. S. L. (2006). The port of Singapore and its governance structure. Research in Transportation Economics, 17(1), 285-310. http://dx.doi.org/10.1016/S0739-8859(06)17013-4

De Langen, P. W. (2004). Governance in Seaport Clusters. Maritime Economics and Logistics, 6(1), $141-156$. http://dx.doi.org/10.1057/palgrave.mel.9100100

Geiger, A. (2009). Modelo de governança para apoiar a inserção competitiva de arranjos produtivos locais em cadeias globais de valor. Tese de Doutorado. Programa de Pós-Graduação em Engenharia de Produção (PPGEP). Universidade Federal do Rio Grande do Sul (UFRGS), Porto Alegre.

Heaver, T. (2006). The Evolution and Challenges of Port Economics. Research in Transportation Economics, 16(1), 11-41. http://dx.doi.org/10.1016/S0739-8859(06)16002-3

Kaplan, R. S., \& Norton, D. P. (1996). Using the Balanced Scorecard as a Strategic Management System. Harvard Business Review, 74(1), 75-85.

Kaplan, R. S., \& Norton, D. P. (2004). Strategy Maps: Converting Intangible Assets into Tangible Outcomes. Boston, MA: Harvard Business School Press.

Lam, J. S. L., Ng, A. K. Y., \& Fu, X. (2013). Stakeholder management for establishing sustainable regional port governance. Research in Transportation Business \& Management, 8(1), 30-38. http://dx.doi.org/10.1016/j.rtbm.2013.06.001

López, R. C., \& Poole, N. (1998). Quality assurance in the maritime port logistics chain: the case of Valencia, Spain. Supply Chain Management, 3(1), 33-44. http://dx.doi.org/10.1108/13598549810200915

Malchow, M. B., \& Kanafani, A. (2004). A disaggregate analysis of port selection. Transportation Research Part E: Logistics and Transportation Review, 40(4), 317-337. http://dx.doi.org/10.1016/j.tre.2003.05.001

Milan, G. S., \& Vieira, G. B. B. (2011). Proposição de um modelo conceitual em torno da prática da governança em cadeias logístico-portuárias. Revista Gestão Industrial, 7(4), 154-174.

Verhoeven, P. (2010). A review of port authority functions: towards a renaissance? Maritime Policy and Management, 37(3), 247-270. http://dx.doi.org/10.1080/03088831003700645 
Vieira, G. B. B., Kliemann Neto, F. J., \& Monfort-Mulinas, A. (2013). O modelo de governança portuária revisitado: Uma contribuição para o processo de reforma portuária. Revista Espacios, 34(10), 6.

World Bank. (2001). Framework for Port Reform. World Bank Port Reform Tool Kit, 1, 1-20. Retrieved from http://www.ppiaf.org/sites/ppiaf.org/files/documents/toolkits/Portoolkit/Toolkit/pdf/modules/01_TOOLKIT _Module1.pdf

Xu, M., \& Chin, A. T. H. (2012). Port governance in China: Devolution and Effects Analysis. Procedia-Social and Behavioral Sciences, 43, 14-23. http://dx.doi.org/10.1016/j.sbspro.2012.04.073

\section{Copyrights}

Copyright for this article is retained by the author(s), with first publication rights granted to the journal.

This is an open-access article distributed under the terms and conditions of the Creative Commons Attribution license (http://creativecommons.org/licenses/by/3.0/). 